\title{
Pengembangan Kewirausahaan Perancangan Busana Pengantin Berbasis Teknologi E-Commerce Pada Lyniza Wedding
}

\author{
Sofyan Azis ${ }^{1}$, Anita Febrianti Ayu Ashari ${ }^{2}$, Hanifah Putri Handayani ${ }^{3}$, Gita Safira Kurnia \\ Dewi ${ }^{4}$, Eni Heni Hermaliani ${ }^{5}$, Sri Rahayu ${ }^{6}$ \\ 123456Universitas Nusa Mandiri \\ e-mail: ${ }^{1}$ sofyanaziz131@gmail.com, ${ }^{2}$ anitafebrianti812@gmail.com, \\ 3hanihandayan@gmail.com, ${ }^{4}$ gitasakude09@gmail.com, ${ }^{5}$ enie h@nusamandiri.ac.id, \\ 6rirahayu.rry@nusamandiri.ac.id
}

\begin{abstract}
Abstrak
Kemudahan dalam mengakses internet merupakan faktor yang sangat penting dalam mengembangkan sebuah usaha. Pada era globalisasi saat ini, situs website E-Commerce menjadi alternatif yang sukses bagi para penggiat bisnis sebagai penunjang pemasaran di dunia internet. Perancangan busana pengantin adalah salah satu bisnis yang sangat populer dimana penting bagi masyarakat yang ingin melangsungkan pernikahan tanpa menggunakan jasa penyewaan. Hal ini berguna untuk para wirausaha jasa penyewaan busana pengantin yang ingin memasarkan busana pengantin bagi pelanggannya. Penelitian ini bertujuan untuk memenuhi tersedianya sistem promosi dapat memudahkan calon pelanggan dalam mengelola informasi produk serta jasa penjahitan atau perancangan busana pengantin, mempermudah calon pelanggan dalam melakukan pemesanan serta mengefisiensikan dalam penyusunan laporan. Adapun metode penelitian yang digunakan yaitu deskriptif analisis melalui pengumpulan data dengan melakukan pengamatan dan wawancara untuk menganalisis rencana usaha, metode pelaksanaan, serta pengembangan usaha. Sedangkan pengembangan sistem untuk rancangan implementasi website menggunakan pendekatan berbasis objek dan platform PHP MySQL. Dengan demikian, penerapan e-Commerce yang akan dikembangkan pada usaha Lyniza Wedding Boutique dapat menangani proses perdagangan yang terdiri dari proses memperoleh informasi berupa katalog busana pengantin sebagai alat promosi dan dapat melakukan pemesanan sesuai yang tertera di katalog website ataupun kustomisasi desain sesuai keinginan calon pelanggan, serta memudahkan karyawan maupun pemilik dalam menyusun laporan.
\end{abstract}

Kata Kunci: Wirausaha, E-Commerce, Busana Pengantin

\begin{abstract}
Ease of accessing the internet is a very important factor in developing a business. In the current era of globalization, the E-Commerce website has become a successful alternative for business activists to support marketing in the internet world. The wedding dress design is a very popular business which is important for people who want to get married without using rental services. This is useful for wedding dress rental service entrepreneurs who want to market wedding dresses to their customers. This study aims to fulfill the availability of a promotional system that can make it easier for prospective customers to manage product information and tailoring services or wedding dress designs, make it easier for prospective customers to place orders, and make reports more efficient. The research method used is descriptive analysis through data collection by conducting observations and interviews to analyze business plans, implementation methods, and business development. Meanwhile, the system developed for the website implementation design uses an object-based approach and the PHP MySQL platform. Thus, the application of e-Commerce that will be developed in the Lyniza Wedding Boutique business can handle the trade process which consists of the process of obtaining information in the form of a bridal fashion catalog as a promotional tool and can place orders as stated on the website catalog or design customization according to the wishes of potential customers, and facilitate employees and owners in compiling reports.
\end{abstract}

Keywords: Entrepreneur, E-commerce, Wedding Dress 


\section{Pendahuluan}

Seiring dengan perkembangan teknologi, proses perdagangan mengarah ke dalam bentuk transaksi tidak langsung. Kehadiran internet sebagai perkembangan teknologi informasi memberikan dampak yang cukup besar dalam dunia perdagangan. Dengan adanya internet, orang yang ingin memasarkan dan menjual dagangannya dapat membuat sebuah online shop, yaitu media sosial dan website sebagai tempat menggelar barang dagangannya.

Calon konsumen dapat melihat barang apa saja yang dijual kemudian membeli dengan alur proses yang sudah tersistem. Model seperti ini disebut dengan Electronic Commerce (E-Commerce).

Keberadaan E-Commerce merupakan alternatif bisnis yang cukup menjanjikan untuk diterapkan pada saat ini, karena E-Commerce memberikan kemudahan bagi kedua belah pihak, baik dari pihak penjual maupun dari pihak pembeli di dalam melakukan transaksi perdagangan di berbagai penjuru.

Setiap usaha pasti mempunyai alur berjalan dan sistem produksi yang berbeda dari segi pengelolaannya maupun produksinya. Di Jakarta sudah cukup banyak butik atau toko yang menjual dan menyediakan berbagai macam desain rancangan busana pengantin. Baik model busana adat maupun internasional. Perancangan busana pengantin adalah salah satu bisnis yang sangat penting bagi masyarakat yang ingin melangsungkan pernikahan tanpa menggunakan jasa penyewaan busana.

Busana pengantin dengan berbahan kebaya adalah jenis busana yang mungkin paling banyak diminati untuk calon pengantin. Busana pengantin kebaya kini juga sudah banyak berbagai model mulai dari kebaya adat sampai busana internasional. Dalam usaha perancangan busana pengantin, pasti selalu menyediakan busana jadi maupun menerima desain dari pelanggan. Dengan demikian pelanggan bisa memilih busana yang sudah terancang ataupun memberikan rancangan desain sesuai dengan keinginan.

Di Lyniza Wedding Boutique masih terkendala dalam media promosi karena masih menggunakan sistem offline dan media sosial seperti instagram dan whatsapp saja. Masih menggunakan telpon atau chating untuk pemesanan jarak jauh serta masih meggunakan sistem manual untuk pencatatan penjualannya. Sehingga kurangnya keefektifan dalam penyusunan laporan penjualan. Untuk mengembangkan usaha serta menambah kepuasan pelanggan pada Lyniza Wedding Boutique, penulis ingin menyediakan fasilitas website, dimana di dalam website tersebut pelanggan dapat memilih busana sesuai desain yang tersedia atau mengirimkan desain yang sudah dirancang kepada penjahit/perancang busana pengantin di Lyniza Wedding Boutique.

Pengertian Bisnis adalah suatu kegiatan yang dilakukan oleh perorangan maupun organisasi yang melibatkan aktivitas produksi, penjualan, pembelian, maupun pertukaran barang atau jasa, dengan tujuan untuk mendapatkan keuntungan atau laba. Kata "bisnis" berasal dari bahasa Inggris, yaitu "business" yang artinya kesibukan. Dalam konteks sederhana, yang dimaksud dengan kesibukan adalah melakukan suatu aktivitas atau pekerjaan yang memberikan keuntungan pada seseorang (Pratama et al., 2019).

Adapun menurut (Efendy et al., 2017) Dilihat dari segi etimologi, kewirausahaan berasal dari kata wira dan usaha. Wira berarti pejuang, pahlawan, manusia unggul, teladan, berbudi luhur, gagah berani, dan berwatak agung. Adapun usaha berarti perbuatan amal, bekerja, berbuat sesuatu. Dengan demikian, wirausaha adalah pejuang atau pahlawan yang berbuat sesuatu.

Menurut Skinner Bisnis adalah pertukaran barang, jasa atau uang yang saling menguntungkan atau memberikan manfaat. Sedangkan menurut arti dasarnya, bisnis memiliki makna sebagai the buying and selling of goods and services. Sedangkan perusahaan bisnis adalah organisasi yang terlibat dalam pertukaran barang, jasa, atau uang untuk menghasilkan keuntungan. (Agung Purnomo, Acai Sudirman, Abdurrozzaq Hasibuan, 2020)

Dalam bisnis atau manajemen, sumber daya merupakan unsur utama dalam membangun sebuah bisnis. Untuk mencapai tujuan yang ingin dicapai diperlukan sebuah sarana manajemen yang terdiri dari Man, Money, Material, Machine, Method dan Market atau yang lebih dikenal dengan $6 \mathrm{M}$. 
Dengan kata lain sarana (tools) atau alat manajemen untuk mencapai tujuan adalah: Man, Money, Material, Method dan Market, kesemuanya itu disebut sumber daya (Firmansyah \& Mahardhika, 2018).

Sama halnya menurut (Sunaengsih, 2017) Aktivitas yang jelas berupa proses manajemen, aktivitas dilakukan untuk mencapai tujuan tertentu dan dilakukan melalui orang lain dengan bantuan sumber daya lain pula, yang dinamakan orang dan sumber daya lain biasa disebut $5 \mathrm{M}$, yaitu Man, Materials, Machine, Methods, dan Money.

\section{Metode Penelitian}

Dalam mengembangkan wirausaha yang sedang dijalankan ini, dilakukan pembangunan website penjualan busana pada Lyniza Wedding, untuk membangun website tersebut penulis menggunakan metode waterfall, yaitu dimulai dari analisis, mendesain sistem, elakukan implementasi, pengujian, dan yang terakhir yaitu peeliharaan sistem. Adapun metode pengumpulan data yang dilakukan sebagai berikut :

\section{Observasi}

Penulis mengamati bahwa Lyniza Wedding dalam melakukan menajemen pemasaran masih dengan cara door to door dan membuat laporan penjualan dengan cara manual yaitu penulisan kertas.

\section{Analisa Masalah}

Pengenalan produk dan brand yang minim, untuk laporan pejualan lebih memakan banyak waktu dan terdapat beberapa laporan penjualan yang terselip dan hilang.

\section{Wawancara}

Melakukan wawancara dengan pemilik butik mengenai proses usaha yang sedang dijalankan seperti manajemen usaha, produksi busana pengantin, cara pemesanan, laporan penjualan serta permasalahan apa yang sedang dihadapi.

\section{Rencana Penyelesaian Masalah}

Penulis membangun website yang bertujuan agar dapat mengembangkan usaha penjualan busana pengantin pada Lyniza Wedding agar dapat memudahkan calon pelanggan dalam mendapat informasi produk dan memesannya, serta mengefisienkan dalam penyusunan laporan penjualan.

Menurut (Rahmawati, 2016) pemasaran merupakan aktivitas yang bertujuan untuk mengidentifikasi dan menemukan kebutuhan manusia. Secara ringkas pemasaran bisa diartikan dengan sebagai "meeting needs profitably" yaitu bagaimana perusahaan bisa melayani kebutuhan konsumen dengan cara yang menguntungkan bagi konsumen dan perusahaan.

Tempat atau bisa disebut sebagai sarana distribusi merupakan kegiatan perusahaan yang saling bergantung serta terlibat dalam proses untuk menjadikan suatu produk atau jasa siap pakai atau dikonsumsi, yang termasuk di dalamnya adalah saluran pemasaran, cakupan pasar, pengelompokan lokasi, persediaan transportasi. (Akhmad Sefudin, 2014)

\section{Hasil dan Pembahasan}

\subsection{Analisa Investasi}

Menurut Kamus Besar Bahasa Indonesia (KBBI) investasi adalah penanaman uang atau modal dalam suatu perusahaan atau proyek untuk tujuan memperoleh keuntungan. Menurut Kastaman (2004) kebutuhan investasi suatu usaha ditentukan berdasarkan peralatan dan bahan yang diperlukan selama jangka waktu usaha tertentu (Cimanggung \& Cimanggung, 2017).

Investor adalah pemodal yang akan membeli atau menanamkan modalnya di perusahaan yang melakukan emisi (Zulfikar, 2016).

Meskipun investor bisa mendapatkan informasi dari berbagai pihak, tetapi keputusan investasi tetap berada di tangan investor. Demikian investor harus menanggung resiko atas keputusan yang di buatnya.

Sebagai salah satu pelaku pasar modal, investor mempunyai tanggung jawab atas resiko yang terjadi (Widoatmodjo, 2015).

Modal usaha sebesar Rp. 3.000.000. Sedangkan biaya tetap dalam 1 bulan sebesar Rp. 1.700.000, terbagi untuk 2 orang gaji pegawai, transportasi, pemeliharaan website dan cetak kartu nama.

Tabel 3.1. Biaya Tetap 1 Bulan 
Biaya variabel per 1 bulan untuk kebaya pendek sebesar Rp. 1.030.000, sedangkan untuk biaya variabel per 1 bulan untuk kebaya panjang sebesar Rp. 1.760.000, biaya tersebut terbagi atas bahan brokat, payet, tile Kristal, aplikasi border, bahan lain-lain, ongkos jahit dan ongkos payet.

Tabel 3.2. Biaya Variabel 1 Bulan Kebaya Pendek Exclusive

\begin{tabular}{|c|c|c|c|}
\hline \multicolumn{4}{|c|}{ 1. Kebaya Pendek Exclusive } \\
\hline $\begin{array}{l}\text { Nama } \\
\text { Biaya }\end{array}$ & Kontribusi & & Total \\
\hline $\begin{array}{l}\text { Bahan } \\
\text { Brokat } \\
\text { 3D } \\
\end{array}$ & $\begin{array}{l}3 \text { meter x } \\
@ R p \\
125.000\end{array}$ & $\mathrm{Rp}$ & 375.000 \\
\hline Payet & $\operatorname{Rp} 25.000$ & $R p$ & 25.000 \\
\hline $\begin{array}{l}\text { Tile } \\
\text { Kristal }\end{array}$ & Rp 30.000 & $\mathrm{Rp}$ & 30.000 \\
\hline $\begin{array}{l}\text { Aplikasi } \\
\text { Bordir }\end{array}$ & Rp 100.000 & $\mathrm{Rp}$ & 100.000 \\
\hline $\begin{array}{l}\text { Bahan } \\
\text { Lain- } \\
\text { Lain }\end{array}$ & Rp 100.000 & $\mathrm{Rp}$ & 100.000 \\
\hline $\begin{array}{l}\text { Ongkos } \\
\text { Jahit }\end{array}$ & Rp 200.000 & $\mathrm{Rp}$ & 200.000 \\
\hline $\begin{array}{l}\text { Ongkos } \\
\text { Payet }\end{array}$ & Rp 200.000 & $\mathrm{Rp}$ & 200.000 \\
\hline \multicolumn{2}{|c|}{ Total } & \multicolumn{2}{|c|}{ Rp 1.030 .000} \\
\hline
\end{tabular}

Tabel 3.3. Biaya Variabel 1 Bulan Kebaya Panjang Exclusive

\begin{tabular}{|c|c|c|c|}
\hline \multicolumn{4}{|c|}{ 2. Kebaya Panjang Exclusive } \\
\hline $\begin{array}{l}\text { Nama } \\
\text { Biaya }\end{array}$ & Kontribusi & \multicolumn{2}{|c|}{ Total } \\
\hline $\begin{array}{l}\text { Bahan } \\
\text { Brokat } \\
\text { 3D } \\
\end{array}$ & $\begin{array}{l}5 \text { meter x } \\
@ R p \\
125.000\end{array}$ & $\mathrm{Rp}$ & 625.000 \\
\hline Payet & Rp 35.000 & $\mathrm{Rp}$ & 35.000 \\
\hline $\begin{array}{l}\text { Tile } \\
\text { Kristal }\end{array}$ & $\operatorname{Rp} 60.000$ & $\mathrm{Rp}$ & 60.000 \\
\hline $\begin{array}{l}\text { Aplikasi } \\
\text { Bordir }\end{array}$ & Rp 150.000 & $\mathrm{Rp}$ & 150.000 \\
\hline $\begin{array}{l}\text { Bahan } \\
\text { Lain- } \\
\text { Lain } \\
\end{array}$ & Rp 190.000 & $\mathrm{Rp}$ & 190.000 \\
\hline $\begin{array}{l}\text { Ongkos } \\
\text { Jahit }\end{array}$ & Rp 300.000 & $\mathrm{Rp}$ & 300.000 \\
\hline $\begin{array}{l}\text { Ongkos } \\
\text { Payet }\end{array}$ & Rp 400.000 & $\mathrm{Rp}$ & 400.000 \\
\hline \multicolumn{2}{|c|}{ Total } & \multicolumn{2}{|c|}{$\operatorname{Rp} 1.760 .000$} \\
\hline
\end{tabular}

\begin{tabular}{|l|l|l|}
\hline Nama Biaya & Kontribusi & Total \\
\hline Gaji Pegawai & $\begin{array}{l}\text { 2 Pegawai x } \\
\text { @Rp } \\
250.000\end{array}$ & $\begin{array}{l}\mathrm{Rp} \\
500.000\end{array}$ \\
\hline Transportasi & Rp 400.000 & $\begin{array}{l}\mathrm{Rp} \\
400.000\end{array}$ \\
\hline $\begin{array}{l}\text { Pemeliharaan } \\
\text { Website }\end{array}$ & Rp 700.000 & $\begin{array}{l}\mathrm{Rp} \\
700.000\end{array}$ \\
\hline $\begin{array}{l}\text { Cetak Kartu } \\
\text { Nama }\end{array}$ & Rp 100.000 & $\begin{array}{l}\mathrm{Rp} \\
100.000\end{array}$ \\
\hline Total & & $\begin{array}{l}\mathbf{R p} \\
\mathbf{1 . 7 0 0 . 0 0 0}\end{array}$ \\
\hline
\end{tabular}

Total omset dalam 1 bulan sebesar Rp. 5.200.000 dari 1 kebaya pendek dan 1 kebaya panjang.

\subsection{Analisis Ekonomi Usaha}

Hasil yang diperoleh dari penjualan selama 3 bulan maka dapat disimpulkan bahwa pada bulan April 2021 mendapat keuntungan sebesar $16 \%$ dan Mei 2021 mendapat keuntungan sebesar 23\% walaupun pada bulan Mei mengalami penurunan penjualan. Keuntungan pada bulan Mei masih merupakan pendapatan yang wajar bagi usaha Lyniza Wedding Boutique. Kemudian pada bulan Juni mengalami penurunan menjadi $16 \%$ keuntungan, hal ini disebabkan karena Lyniza Wedding Boutique memberikan potongan harga kepada pelanggannya. Bahkan dapat dikatakan hanya mengambil keuntungan yang sedikit.

Berdasarkan dari analisis cash flow terhadap modal perencanaan usaha sebesar Rp 3.000.000, pada usaha Lyniza Wedding Boutique dapat menghasilkan 6 (enam) buah busana pengantin selama tiga bulan yang rata - rata adalah busana atau kebaya untuk wanita. Pada periode April s.d. Juni 2021 terjual 2 kebaya pendek, 3 kebaya panjang dan 1 gaun panjang berekor dengan memberikan potongan harga atau diskon sebagai bentuk promosi. Dengan total keseluruhan penjualan Rp.16.200.000.

Pada proses produksi dan penjualan busana pengantin pada Lyniza Wedding Boutique, membutuhkan biaya tetap dan biaya lain - lain selama periode April - Juni 2021. Beban biaya tersebut di peruntukan untuk biaya gaji karyawan, biaya transportasi dan beban biaya produksi.

a. Biaya tetap gaji karyawan periode April

- Juni 2021

= Gaji karyawan $\times$ Periode

$=\operatorname{Rp} 500.000 \times 3$ bulan

$=\operatorname{Rp} 1.500 .000$ 
b. Biaya Tetap (Beban biaya transportasi) periode April - Juni 2021

$=$ Transportasi $\times$ Periode

$=$ Rp $400.000 \times 3$ bulan

$=\operatorname{Rp} 1.200 .000$

C. Biaya promosi

$=\operatorname{Rp} 100.000$

d. Total beban biaya tetap \& biaya promosi periode April - Juni 2021

= Biaya tetap + biaya promosi

$=\operatorname{Rp} 4.700 .000+\operatorname{Rp} 100.000$

$=\operatorname{Rp~4.800.000}$

Dengan modal sebesar Rp

3.000.000 ditamabah total pendapatan penjualan busana pengantin Lyniza Wedding Boutique periode April s.d. Juni 2021 senilai $\mathrm{Rp} 16.200 .000$ dan dikurangi biaya 148ariable, biaya tetap dan biaya lain - lain selama periode April s.d. Juni 2021 senilai $R p$ 10.780.000. Sehingga saldo kas yang tersisa pada bulan Juni 2021 adalah senilai Rp 8.420.000.

Usaha yang di kembangkan pada periode April s.d. Juni 2021 memperoleh sisa saldo kas pada Juni 2021 senilai Rp Rp 8.420.000 dengan hasil yang diperoleh sudah dapat mengembalikan modal yang dikeluarkan. Usaha perancangan busana pengantin pada Lyniza Wedding Boutique sangat memiliki peluang yang besar untuk mendapatkan keuntungan. Jika penjualan kedepannya dengan asumsi penjualan meningkat maka diperkirakan biaya produksi juga akan menyesuaikan total penjualan atau pendapatan yang diperoleh.

Adapun diagram alur produksi usaha pada lyniza wedding boutique, meliputi :

1. Mempersiapkan alat dan bahan yang dibutuhkan sesuai pesanan pelanggan

2. Membuat desain busana yang akan di rancang

3. Membuat pola busana

4. Memotong pola yang sudah di rancang sesuai dengan desain yang dibutuhkan

5. Memotong bahan sesuai dengan pola yang sudah di rancang

6. Menjahit bahan yang sudah sudah dipotong sesuai dengan pola

7. Mulai mengaplikasikan bahan

8. Membuat bordiran sesuai desain

9. Memasang payet sesuai dengan desain busana

10. Melakukan pengecekan busana beserta fitting terhadap pelanggan

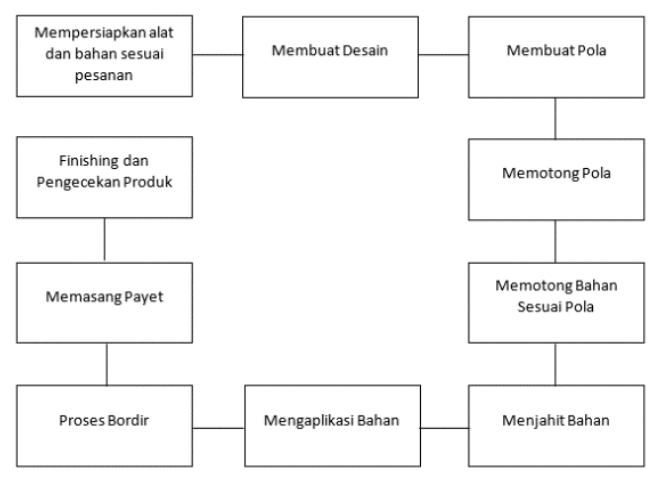

Gambar 3.1. Diagram Alur Produksi

\subsection{Pengembangan Pemasaran Bisnis}

Terdapat beberapa pengembagan

untuk pemasaran bisnis, diantaranya:

1. Publikasi melalui media cetak (kartu nama)

Dalam melakukan promosi dengan menyebar atau membagikan kartu nama pada saat acara bazar atau pameran kepada pengunjung dapat memberikan peluang ketertarikan calon pelanggan kepada produk yang ditawarkan.

2. Publikasi melalui media internet

Dalam melakukan promosi juga memanfaatkan media online melalui media sosial seperti instagram. Karena hampir semua kalangan sudah menggunakan aplikasi media sosial tersebut.

3. Website

Website ini berfungsi sebagai salah satu strategi pemasaran guna mempromosikan produk dan jasa perancangan busana pengantin.

Adapun analisis sistem yang berjalan memberikan gambaran tentang sistem pada Lyniza Wedding Boutique yang saat ini sedang berjalan. Analisa sistem yang sedang berjalan ini bertujuan untuk mengetahui tahapan - tahapan yang menerangkan mengenai proses apa yang sedang dikerjakan. Berikut akan terlihat jelas dalam flowchart sebagai berikut: 


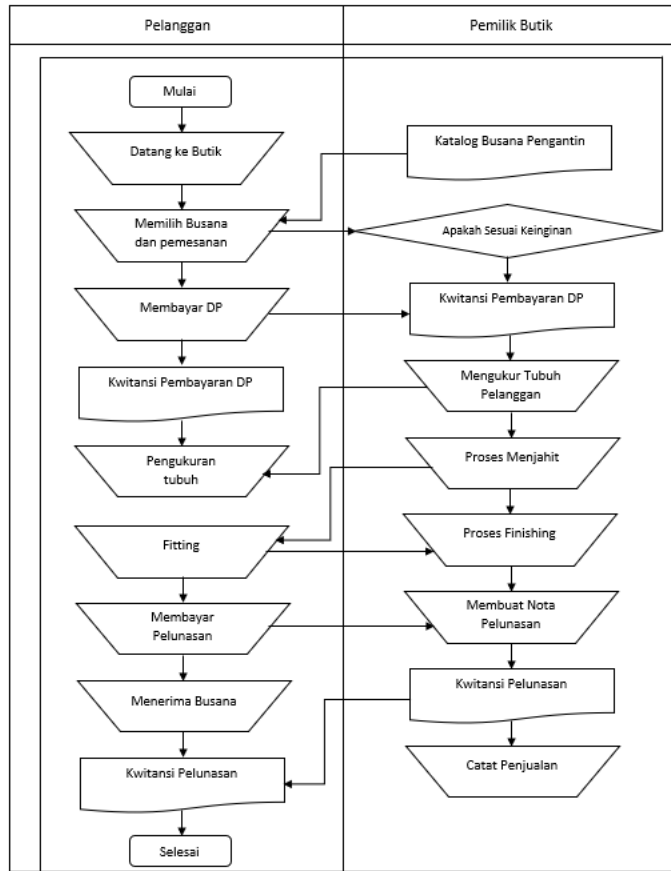

Gambar 3.2. Flowchart Analisis Sistem Berjalan

Pada gambar dijelaskan bahwa sistem yang sedang berjalan yaitu calon pelanggan memesan busana pengantin dengan cara datang langsung kemudian dilakukan perancangan busana pengantin sesuai keinginan calon pelanggan. Pada saat perancangan busana pengantin dibantu oleh beberapa pegawai untuk proses memasang payet, bordir dan lainlain.

Rancangan sistem yang diusulkan dirancang untuk memberikan gambaran aliran data yang ada pada program sistem informasi yang akan dibangun. Tahapan tahapan yang ada yaitu dengan mengkonfigurasi dari komponen komponen perangkat lunak dan perangkat keras sistem. Adapun sebagai alat batu yang digunakan untuk menggambarkan sistem secara umum.(Irawan \& Rozando, 2020)

\subsection{Desain Sistem}

Desain sistem yang dibangun terdiri dari desain proses bisnis dan desain database yang dijelaskan sebagai berikut:

\section{Use Case Diagram Admin}

Pertama admin harus melakukan login terlebih dahulu, lalu admin dapat mengupdate data kategori, data produk, data size dan data ongkos kirim, admin juga dapat melihat status pemesanan dan bukti pembayaran pelanggan, selain itu admin dapat melihat dan menghapus data upload desain pelanggan dan data pelanggan, dapat mengupdate informasi kontak dan alamat butik, dapat melihat/mengunduh/mencetak laporan pembelian dan laporan upload desain, serta dapat melihat/membalas/mengirim pesan.

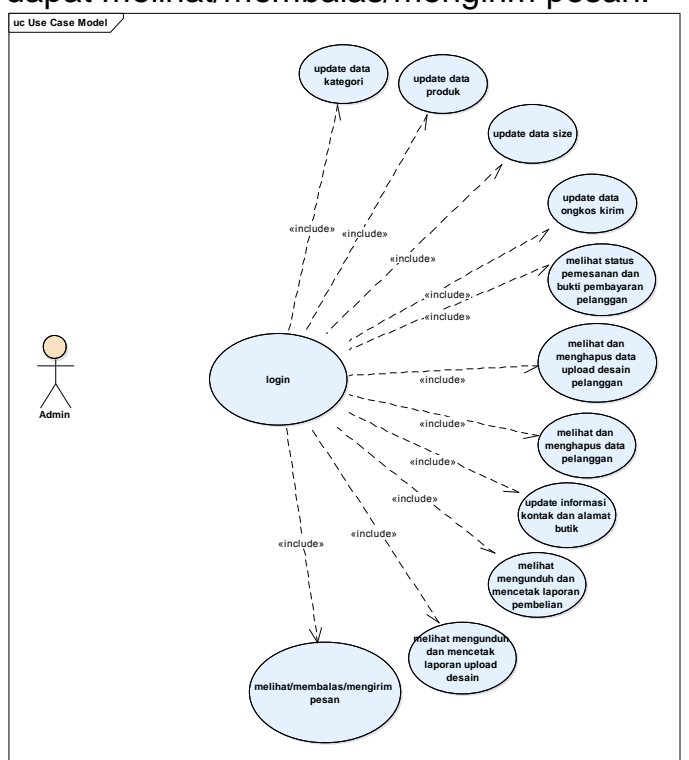

Gambar 3.3. Use Case Diagram Admin pada website Lyniza Wedding

\section{Use Case Diagram Pelanggan}

Pelanggan diwajibkan untuk mendaftar terlebih dahulu, jika berhasil maka pelanggan harus melakukan login, pelanggan dapat melihat kategori, dapat melihat detail produknya, lalu melakukan pemesanan, jika memesan maka pesanan akan masuk keranjang, lalu melakukan checkout dengan mengisi form pemesanan, disitu pelanggan dapat custom desain ataupun tidak, lalu diarahkan ke menu pembayaran. Selain itu pelanggan dapat mengecek riwayat belanja serta dapat melihat kontak dan alamat butik.

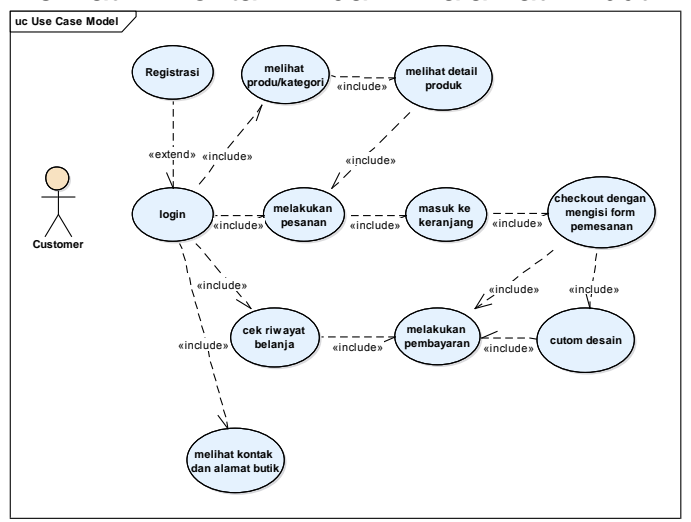


Gambar 3.4. Use Case Diagram Pelanggan pada website lyniza wedding

\section{Activity Diagram}

Calon pelanggan harus memulai dengan registrasi tetapi tidak dengan admin, setelah itu bisa login sebagai pelanggan, sistem akan memvalidasi akun pelanggan saat login, jika tidak berhasil akan kembali pada halaman login, jika berhasil akan muncul halaman beranda, begitupun dengan admin, pelanggan bisa memilih kategori, memilih produk, lalu melihat detail produk dan melakukan pemesanan dan akan tersimpan pada keranjang, pelanggan harus mengisi form pemesanan (dan custom desain jika dibutuhkan), setelah itu akan menampilkan detail pemesanan, dan pelanggan akan diarahkan ke halaman pembayaran, lalu konfirmasi pembayaran, pelanggan dapat mengecek status pesanan dan sistem akan menampilkannya maka pesanannya akan diproses oleh pihak admin, Setelah login admin pun dapat mengupdate kategori, produk, size, data ongkir, info butik, melihat data pelanggan, melihat serta mengkonfirmasi pesanan dan melihat serta mencetak laporan penjualan.

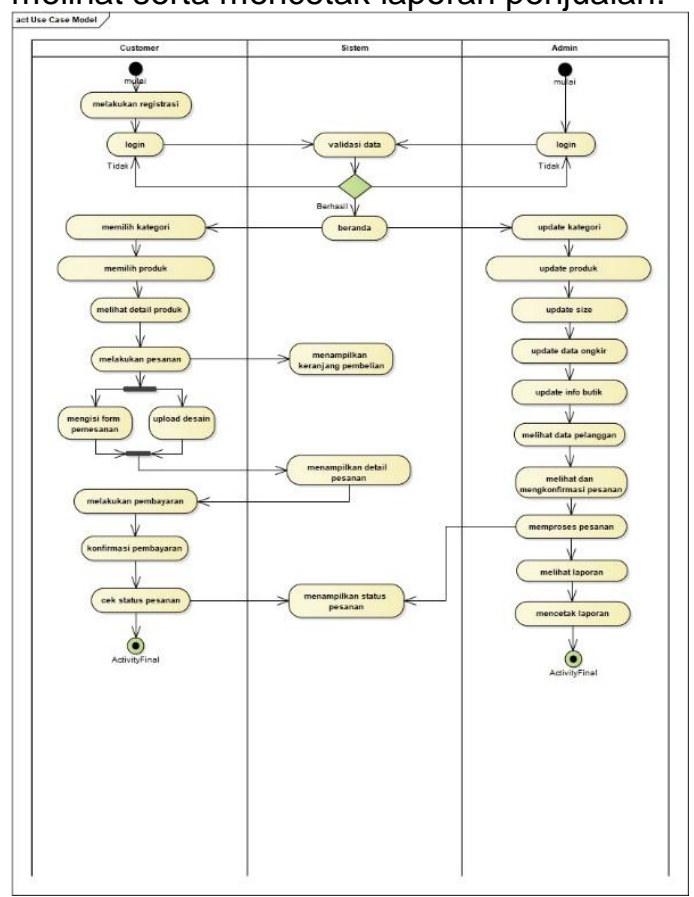

Gambar 3.5. Activity Diagram pada Website Lyniza Wedding

\section{Entity Relationship Diagram}

pelanggan dapat memilih kategori, dapat memilih produk, langsung ditampilkan kerajang, didalam keranjang dapat melakukan upload desain, selain itu didalam keranjang juga dapat melakukan pembelian produk, lalu pembelian produk diproses admin, menjadi status, didala status menampilkan laporan pembelian. didala pebelian produk pun dapat menampilkan pembayaran, setelah itu menampilkan pebelian.

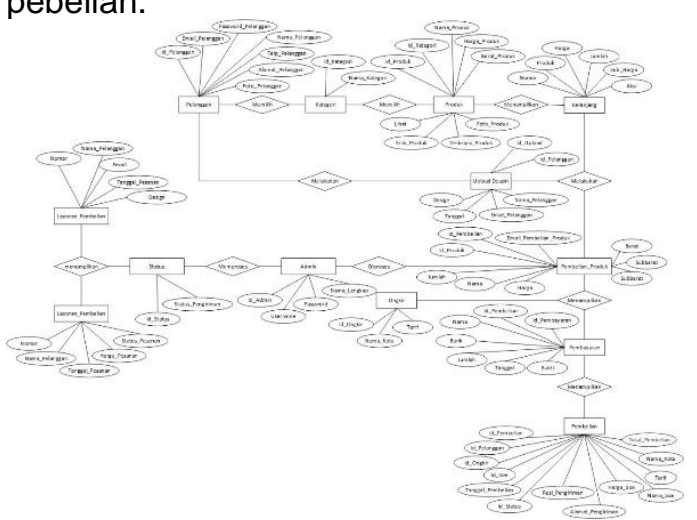

Gambar 3.6. Entity Relationship Diagram (ERD) pada Website Lyniza Wedding

\section{Logical Record Structure}

Adapun tabel tabel yang dibuat adalah:

1. Tabel admin berisi biodata admin terdapat user login dan password untuk akses masuk

2. Tabel pelanggan berisi keseluruhan biodata pelanggan yang telah mengakses situs web

3. Tabel produk berisi keseluruhan jenis produk yang dipasarkan

4. Tabel produk foto berisi gambar produk

5. Tabel kategori

6. Tabel pembelian

7. Tabel pembelian produk

8. Tabel info butik

9. Tabel upload

10. Tabel size

11. Tabel pembayaran

12. Tabel ongkir

13. Tabel status

Berikut basis data yang terdapat pada lyniza wedding yang sudah dibuat dan disusun sesuai dengan kebutuhan website. berikut basis data lynizawedding dengan detail primary key dan foreign key yang telah dirancang demi keamanan dan validitas proses data. 

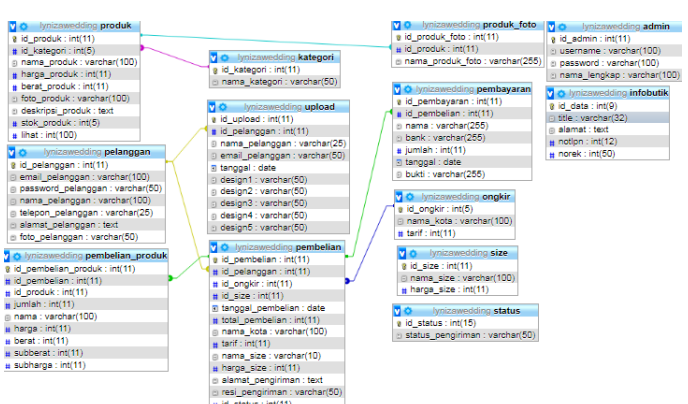

Gambar 3.7. Logical Record Structure (LRS) pada Website Lyniza Wedding

Logical Record Structure Adalah representasi dari struktur record-record pada tebel-tabel yang terbentuk dari hasil antar himpunan entitas. Berikut gambar LRS Pengembangan Kewirausahaan Perancangan Busana Pengantin Berbasis Teknologi E-Commerce pada Lyniza Wedding Boutique.(Yusuf Sukman, 2017)

Berikut implementasi website yang penulis rancang dengan sederhana:

1. Halaman Admin

\section{Halaman Home}

Halaman home admin merupakan halaman yang ditampilkan pertama kali pasa saat admin berhasil login. Pada halaman home admin seperti gambar diatas menjelaskan bagaimana media asmin dapat berjalan, serta seperti apa admin menggunakan setiap menu yang ada.

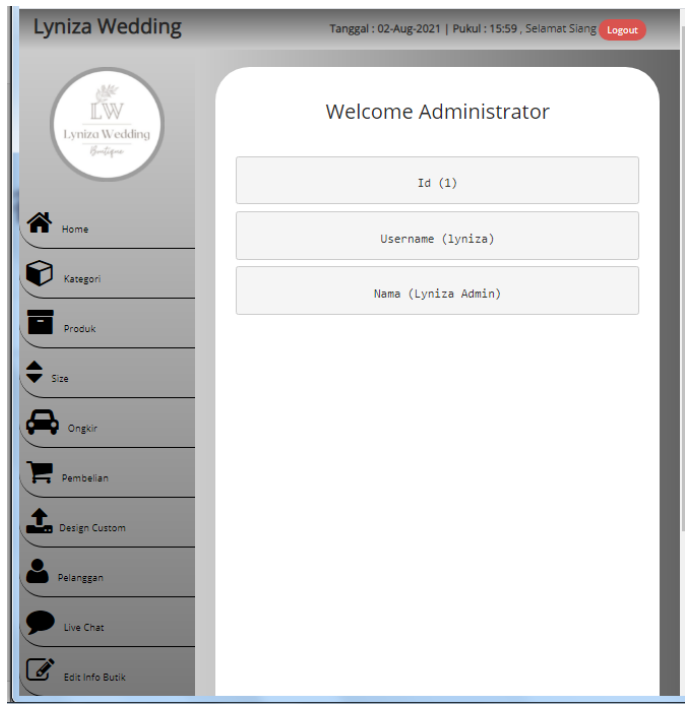

Gambar 3.8. Halaman Home Admin

\section{Halaman Data Kategori}

Pada halaman data kategori ini memuat daftar kategori busana yang mengklasifikasikan daftar produk tertentu. Pada halaman ini admin dapat

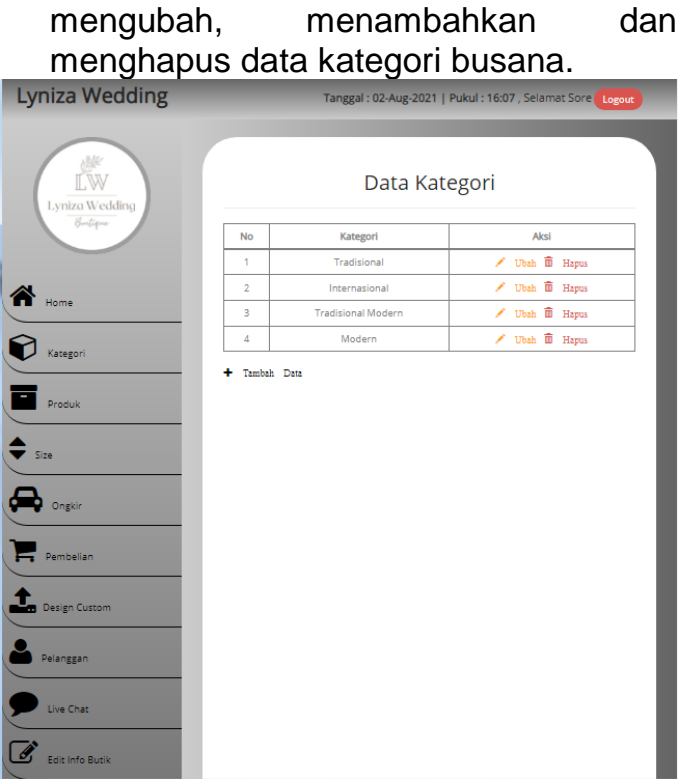

Gambar 3.9. Halaman Kategori

\section{Halaman Data Produk}

Pada halaman data produk ini menjelaskan jika admin meng-klik menu produk, maka akan memuat daftar busana Lyniza Wedding Boutique. Pada halaman ini admin dapat mengubah, menambahkan dan menghapus data produk.

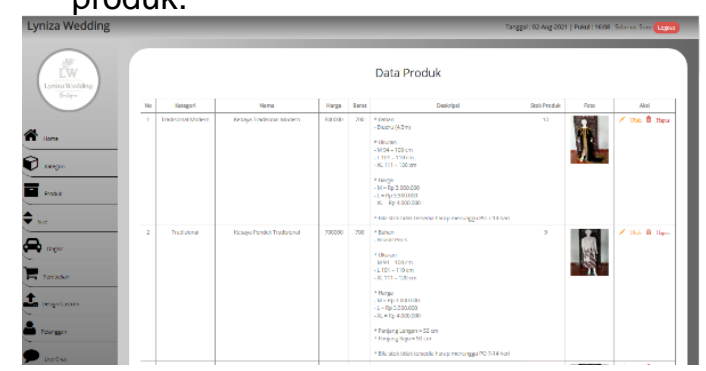

Gambar 3.10. Halaman Data Produk

\section{Halaman Data Pembelian}

Halaman data pembelian memuat data pemesanan masuk. Pada halaman ini Admin dapat melihat status pemesanan dan bukti pembayaran pelanggan.

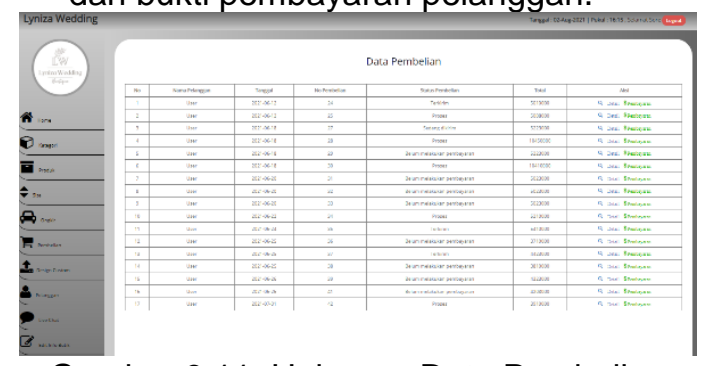

Gambar 3.11. Halaman Data Pembelian

Halaman Custom Desain 
Dalam halaman upload desain admin memuat daftar busana yang dipesan melalui menu upload desain pada pelanggan. Pada halaman ini admin dapat melihat dan menghapus data upload desain dari pelanggan.

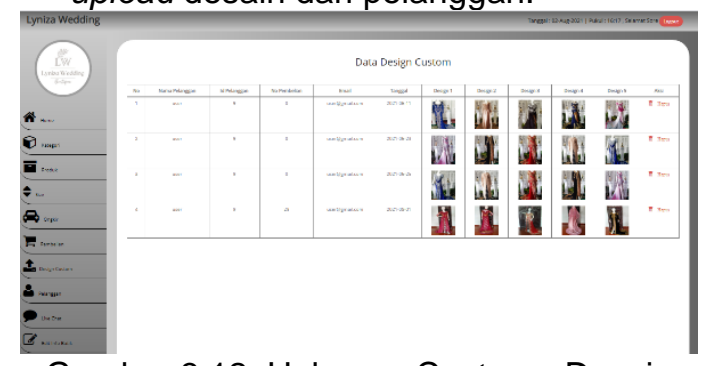

Gambar 3.12. Halaman Custome Desain

\section{Halaman Data Pelanggan}

Halaman data pelanggan memuat daftar pelanggan yang sudah melakukan registrasi pada website Lyniza Wedding Boutique. Pada halaman ini admin dapat melihat dan menghapus data pelanggan

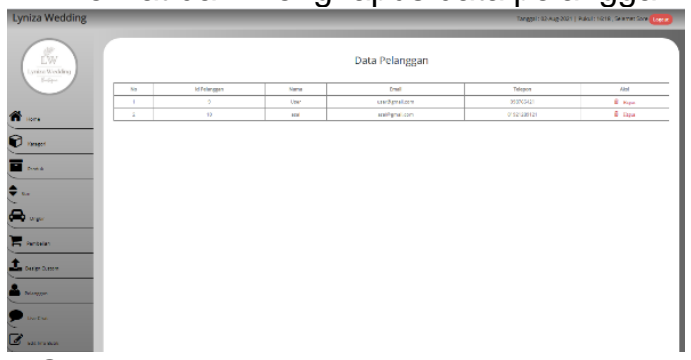

Gambar 3.13. Halaman Data Pelanggan

\section{Halaman Data Butik}

Dalam halaman data butik ini, admin dapat menghapus dan mengedit mengenai informasi kontak dan alamat butik.

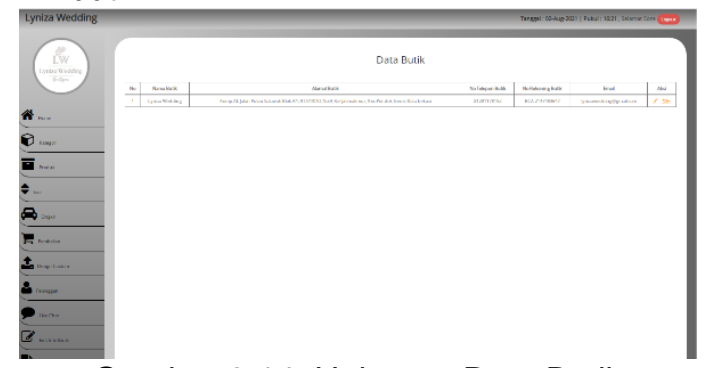

Gambar 3.14. Halaman Data Butik

\section{Halaman Pelanggan}

\section{Halaman Daftar atau Registrasi}

Sebelum dapat melakukan login dan melakukan pemesanan calon pelanggan diwajibkan untuk mendaftar sebagai pelanggan dengan mengisi form untuk validasi akun.

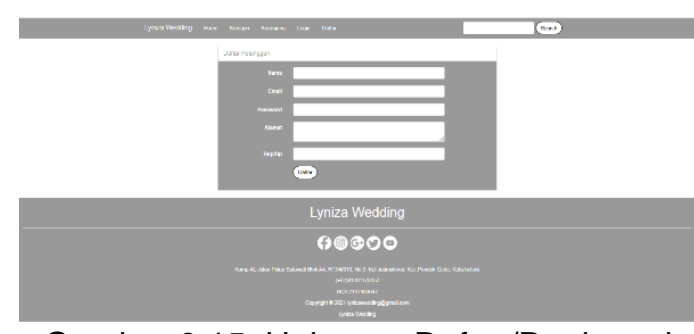

Gambar 3.15. Halaman Daftar/Registrasi

\section{Halaman Kategori}

Dalam halaman kategori pelanggan dapat meng-klik salah satu kategori busana kemudian website akan menampilkan busana sesuai kategori yang dipilih kemudian pelanggan dapat memilih produk atau busana sesuai dengan keinginan.

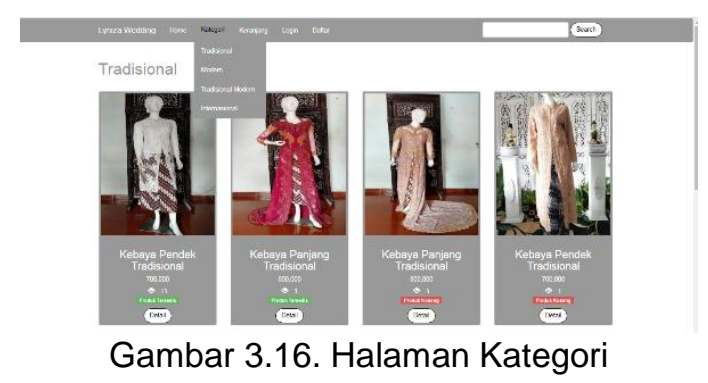

Halaman Detail Produk

Pada halaman detail produk memuat informasi busana. Kemudian pelanggan dapat meng-klik pesan untuk melakukan pemesanan busana pengantin.

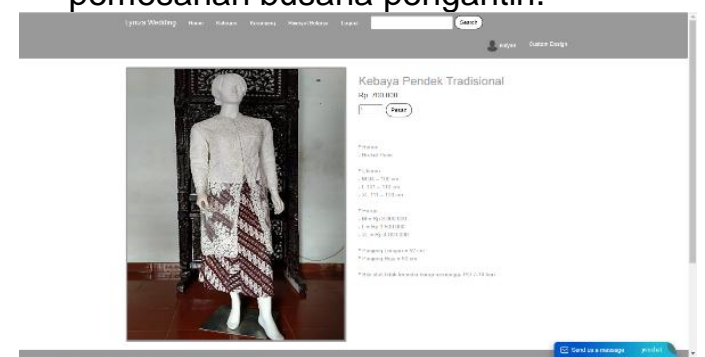

Gambar 3.17. Halaman Detail Produk

\section{Halaman Keranjang}

Halaman ini muncul setelah pelanggan meng-klik menu pesan pada halaman detail produk.

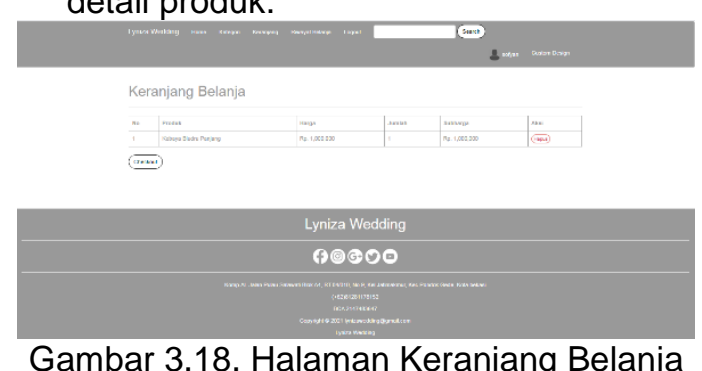

Gambar 3.18. Halaman Keranjang Belanja 


\section{Halaman Checkout Belanja}

Setelah memilih produk, pelanggan harus mengisi form pemesanan di dalam form checkout. Pelanggan harus memilih size dan memilih kota tujuan untuk mengetahui total harga yang harus dibayarkan setelah melakukan pemesanan.

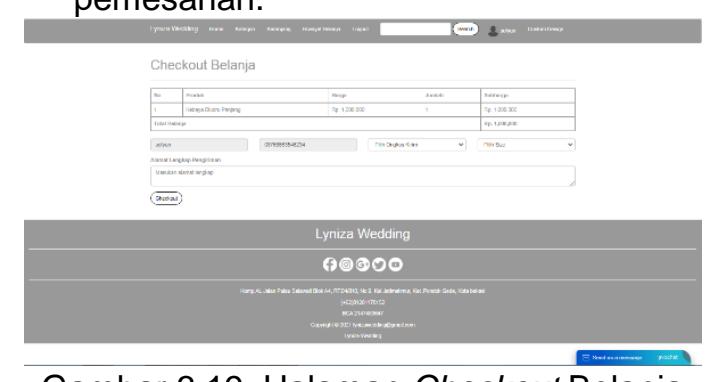

Gambar 3.19. Halaman Checkout Belanja

\section{Halaman Detail Pembelian}

Setelah pelanggan sudah mengisi form dan melakukan checkout, halaman langsung diarahkan ke detail pembelian. Dimana tertera informasi untuk melakukan pembayaran.

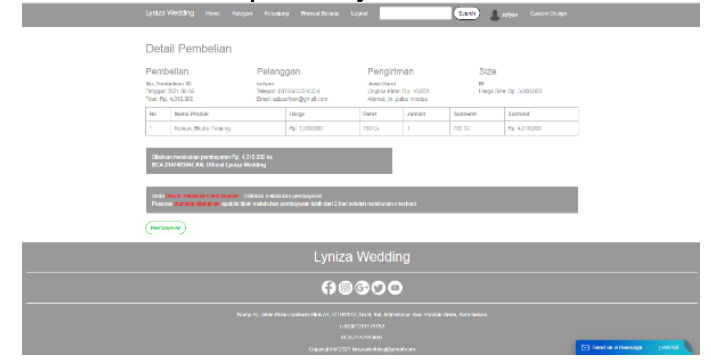

Gambar 3.20. Halaman Detail Pembelian

\section{Halaman Riwayat Belanja}

Pada halaman riwayat belanja memuat opsi untuk melakukan konfirmasi pembayaran kepada admin setelah melakukan pembayaran dengan mengklik menu Pembayaran

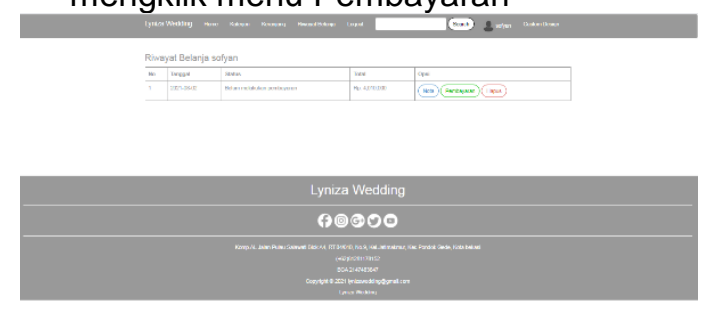

Gambar 3.21. Halaman Riwayat Belanja

Halaman Konfirmasi Pembayaran

Pada halaman ini pelanggan harus mengisi form sebagai bukti bahwa sudah melakukan pembayaran

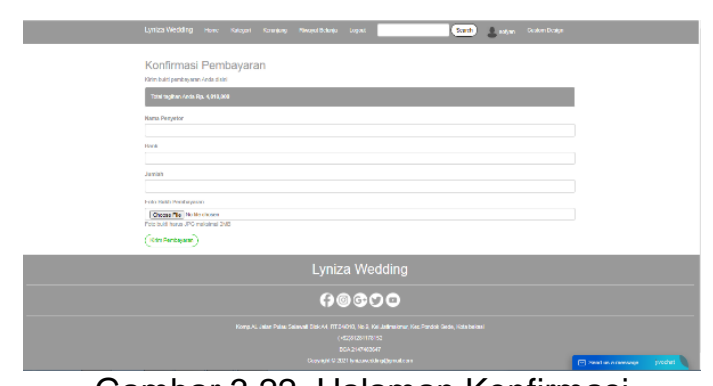

Gambar 3.22. Halaman Konfirmasi Pembayaran

\section{Kesimpulan}

Dengan permasalahan sistem pemasaran yang hanya mengandalkan sosial media dan penyusunan laporan penjualan yang masih manual merupakan faktor kurang berkembangnya usaha pada Lyniza Wedding Boutique sehingga penjualan tidak mengalami peningkatan atau bisa dikatakan stabil. Setelah melakukan analisa penghasilan dari penjualan dari bulan April sampai dengan Juli 2021 memang sudah sangat menguntungkan namun dari jumlah busana yang terjual masih dikatakan sangat sedikit. Oleh sebab itu, penulis melakukan pengembangan usaha khususnya dalam segi pemasaran dan transaksi penjualan busana pengantin. Dengan dirancangnya sebuah website e-commerce dapat memudahkan calon pelanggan mengelola informasi dan melakukan pemesanan busana pengantin. Serta mempermudah karyawan dan pemilik usaha dalam penyusunan laporan penjualan.

Penulis berpendapat untuk perbaikan selanjutnya website e-commerce penjualan busana pengantin pada Lyniza Wedding Boutique dapat dikembangkan lagi ke sistem android ataupun lainnya, Pengembangan sistem dengan fitur yang lebih menarik lagi seperti fitur rekening virtual dan lainnya, Memberikan potongan harga atau diskon kepada pelanggan maupun calon pelanggan setiap bulannya, serta selalu melakukan inovasi desain dan membuka jenis usaha baru yang berkaitan dengan brand.

\section{Referensi}

Agung Purnomo, Acai Sudirman, Abdurrozzaq Hasibuan, D. (2020). Dasar-Dasar Kewirausahaan: Untuk Perguruan Tinggi dan Dunia Bisnis (Issue February 2021). 
JURNAL SWABUMI, Vol.9 No.2 September 2021, pp. 144 154

ISSN: 2355-990X

Akhmad Sefudin. (2014). REDEFINISI BAURAN PEMASARAN (MARKETING MIX) "4P" ke "4C" (Studi Kasus pada Universitas Indraprasta PGRI). Journal OfApplied Business and Economics Volume, 1(1), 17-23.

Cimanggung, D. I. D., \& Cimanggung, K. (2017). Analisis Ekonomi Dan Nilai Tambah Produksi Emping Jagung [ Economic and Added Value Analysis of Cornflakes Production in Cimanggung District, Sumedang Regency ]. 6(1), 11-20.

Efendy, R., Sjahruddin, H., \& Anto, A. (2017). Praktik Motivasi Kerja dan Konsekuensinya Pada Kinerja Aparatur Sipil Negara. https://doi.org/10.31227/osf.io/6gujt

Firmansyah, M. A., \& Mahardhika, B. W. (2018). Pengantar Manajemen. Deepublish.

Irawan, P. lucky tirma, \& Rozando, D. (2020). Rancang Bangun Sistem Ecommerce Clothing Store dan Modul Custom Design Lab Terintegrasi. Smatika Jurnal, 10(01), 1-9. https://doi.org/10.32664/smatika.v1 0i02.397

Pratama, A., Mukaromah, S., \& Ayu I, S. (2019). Analisis Dan Perancangan Sistem Informasi Kewirausahaan Mahasiswa Sebagai Media Pemasaran Unit Usaha (Studi Kasus: Upn Veteran Jawa Timur). SCAN - Jurnal Teknologi Informasi Dan Komunikasi, 14(3), 39-44. https://doi.org/10.33005/scan.v14i3. 1686

Rahmawati. (2016). Manajemen Pemasaran. University Mulawarman, 4-5.

Sunaengsih, C. (2017). Buku Ajar Pengelolaan Pendidikan. UPI Sumedang Press.

Widoatmodjo, S. (2015). Pengetahuan Pasar Modal Untuk Konteks Indonesia. Kompas Gramedia.

Yusuf Sukman, J. (2017). Опыт аудита обеспечения качества и безопасности медицинской деятельности в медицинской организации по разделу «Эпидемиологическая

безопасностьNo Title. Вестник Росздравнадзора, 4, 9-15.
Zulfikar. (2016). Pengantar Pasar Modal dengan Pendekatan Statistika. Deepublish. 